\title{
TEMA CINTA DALAM NOVEL SHIOSAI KARYA MISHIMA YUKIO
}

\author{
Oleh: \\ *Zaki Ainul Fadli, Nur Hastuti \\ Prodi S1 Sastra Jepang Fakultas Ilmu Budaya Universitas Diponegoro \\ Jl. Prof. Soedharto, S.H., Tembalang Semarang \\ zakiaf@undip.ac.id
}

\begin{abstract}
This paper is titled Theme of Love in Mishima Yukio's Shiosai. The purpose of writing is to reveal the major themes in Mishima Yukio's Shiosai and its relationship to other structures, especially figures and characters, plots and backgrounds. The analysis uses structural methods that have the concept that in a building of a literary work consists of interrelated and inseparable structures. The results of this paper indicate that the theme of love is a major theme that is evidenced by the correlation and relationship of love problems with other structures, especially figures and characterizations, plot, and background.
\end{abstract}

\section{Keywords : Shiosai, novel structures, theme of love}

\section{PENDAHULUAN}

Novel adalah karangan yang panjang dan berbentuk prosa dan mengandung rangkaian cerita kehidupan seseorang dengan orang lain di sekelilingnya dengan menonjolkan watak dan sifat setiap pelaku. Novel adalah media penuangan pikiran, perasaan, dan gagasan penulis dalam merespon kehidupan di sekitarnya. Ketika di dalam kehidupan sekitar muncul permasalahan baru, nurani penulis novel akan terpanggil untuk segera menciptakan sebuah cerita ${ }^{1}$.Hal ini berarti penulis/pengarang karya sastra menuangkan segala ide kreatifnya dari kejadian yang dialami oleh penulis/pengarang itu sendiri atau orang lain menjadi sebuah karya sastra.

Novel menurut Stanton (2007: 90) mampu menghadirkan perkembangan satu karakter, situasi sosial yang rumit, hubungan yang melibatkan banyak atau sedikit karakter, dan berbagai peristiwa rumit yang terjadi beberapa waktu silam

\footnotetext{
${ }^{1}$ http://digilib.uinsby.ac.id/10874/5/bab\%202.pdf
}

secara lebih mendetail. Dengan demikian dalam novel, pelukiskan tentang perkembangan watak tokoh digambarkan secara lebih lengkap. Novel menawarkan sebuah dunia, dunia imajinatif, yang menampilkan rangkaian cerita kehidupan seseorang yang dilengkapi dengan peristiwa, permasalahan, dan penonjolan watak setiap tokohnya ${ }^{2}$. Hal ini juga ada dalam karya sastra Jepang seperti novel yang memiliki keunikan sendiri dalam setiap ceritanya, seperti dalam novel Shiosai karya Mishima Yukio. Mishima bukan hanya dikenal sebagai pengarang Jepang, tetapi juga sebagai pengarang dunia. Pada tahun 1952, ia mengunjungi Yunani, negara yang begitu dikaguminya sejak anak-anak. Unsur-unsur Yunani tampak dalam Novel Shiosai yang diterbitkan tahun 1954, dan inspirasinya berasal dari legenda YunaniDaphnis and Chloe . $^{3}$.

\footnotetext{
${ }^{2}$ http://www.bukukerja.com/2014/01/hakikat-novelsebagai-karya-sastra.html

${ }^{3}$ http://www.mishimayukio.jp/history.html
} 
Novel Shiosai merupakan salah satu hasil karya Mishima Yukio yang berhasil mendapatkan penghargaan Shinchosha Literary Prize. Novel ini mengangkat tema dengan kisah percintaan yang rumit, yaitu tokoh Shinji seorang pemuda nelayan miskin dengan Hatsue seorang gadis kaya di sebuah desa di daerah pesisir Jepang yang sangat terpencil yang bernama Uta Jima. Gelombang fitnah yang sangat keras menjadi tantangan atas keteguhan hati mereka. Inilah sebuah kisah tentang cinta pertama yang sekaligus keras yang bisa mungkin terjadi pada siapapun dan dimanapun. Novel ini menarik untuk dikaji karena mengungkap kisah cinta yang universal dan sekaligus mengungkap cinta yang khas dalam budaya masyarakat Jepang- yang tercermin dalam Novel Shiosai. Berdasarkan hal tersebut, tulisan ini bertujuan untuk mengungkap bagaimana tema mengenai cinta diungkap dalam Novel Shiosai karya Mishima Yukio.

\section{METODE PENELITIAN}

Metode yang digunakan pada penelitian ini adalah metode struktural yang bertumpu pada pendekatan objektif dan strukturalisme yang mnganalisis jalinan unsur-unsur struktur karya sastra dalam pembentukan suatu gagasan dan makna tertentu.Teori strukturalisme adalah sebuah teori pendekatan terhadap teks-teks sastra yang menekankan keseluruhan relasi antara berbagai teks (Hartoko, 1986: 135136). Studi strukturalisme menolak campur tangan pihak luar. Analisis struktural memiliki tujuan untuk membongkar dan memaparkan dengan cermat keterkaitan semua anasir karya sastra yang bersamasama menghasilkan makna menyeluruh.Menurut Yasa, strukturalisme memandang teks sebagai sebuah struktur. Struktur tersebut dibangun oleh sejumlah unsur yang saling berhubungan dalam rangka mencapai keutuhan tunggal (2012: 23). Selain itu, Nurgiyantoro berpendapat bahwa strukturalisme dapat dipandang sebagai salah satu pendekatan kesastraan yang menekankan pada kajian antar hubungan antar unsur pembangun karya yang bersangkutan (2000: 3637).Nurgiyantoro mengutarakan bahwa unsur intrinsik (intrinsic) adalah unsurunsur yang membangun karya sastra itu sendiri (2000: 23). Unsur intrinsik terdiri dari tema, tokoh dan penokohan, alur, latar, sudut pandang, dan amanat.Sebagai salah satu pendekatan, Teeuw (dalam Pradopo, 2012: 141) mengatakan analisis struktural ini merupakan prioritas pertama sebelum yang lain-lain.

Sedangkan mengenai konsep cinta digunakan konsep cinta menurut Erich Fromm yang menguraikan empat unsur dalam perasaan cinta sebagai berikut. Yang pertama adalah adanya care (perhatian). Perhatian ini sangat diperlukan dalam perilaku yang disebut cinta agar dapat memahami kehidupan, perkambangan maju mundur, baik burut, dan bagaimana kesejahteraan objek yang dicintai. Yang kedua adalah adanya responsibility (tanggung jawab). Tanggung jawab diperlukan dalam menjalin hubungan. Sebab tanpa adanya tanggung jawab tidak akan ada pembagian yang seimbang. Tanggung jawab disini bukanlah untuk mendikte objek yang dicintai sekehendak kita, tapi bagaimana keterlibatannya dalam kehidupan objek yang dicintai. Yang ketiga adalah adanya respect (hormat). Perasaan cinta mengandung unsur respect, menghargai dan menerima objek yang dicintai apa adanya dan tidak bersikap sekehandak hati. Sedangkan yang keempat adalah adanya knowledge (pengetahuan). Pengetahuan diperlukan guna mengetahui seluk beluk yang dicintai. Dengan demikian kita dapat membidik target yang kita incar, dengan kata lain tidak kenal maka tidak sayang. Bila objek yang kita bidik itu adalah manusia, maka harus kita kenali dan pahami bagaimana kepribadiannya, latar belakang yang membentuknya, dan 
kecenderungan dirinya ${ }^{4}$. Hal ini berarti bahwa manusia yang memiliki konsep cinta dalam hidupnya adalah manusia yang memiliki rasa perduli, rasa menghargai dan menghormati, adanya perhatian kepada orang lain atau sekitar serta pengetahuan tentang memahami seseorang atau manusia berdasar latar belakang dan lain sebagainya.

\section{PEMBAHASAN}

\subsection{Tema dan Hubungan Antar Strukur}

Tema adalah gagasan dasar umum yang menopang sebuah karya sastra yang terkandung di dalam teks sebagai stuktur semantis dan menyangkut persamaanpersamaan atau perbedaan-perbedaan (Hartoko \& Rahmanto, 1986;142). Berdasarkan tingkat keutamaannya, tema dibagi menjadi tema mayor dan tema minor. Tema mayor adalah makna pokok cerita yang menjadi dasar atau gagasan dasar umum karya tersebut, atau bisa juga disebut tema yang paling utama.Tema minor adalah makna yang terdapat pada bagian cerita atau bisa disebut sebagai tema sebagian. Dengan demikian banyak sedikitnya tema minor tergantung pada banyak sedikitnya makna tambahan yang dapat ditafsirkan dari sebuah cerita novel.

Berdasarkan dikotominya, tema dibagi menjadi tema tradisional dan nontradisional. Tema tradisional adalah hal-hal yang dianggap otomatis terjadi sendiri di masyarakat. Pernyataan-pernyataan tema yang dapat dipandang sebagai bersifat itu misalnya berbunyi, " Kebenaran dan keadilan mengalahkan kejahatan, tindak kebenaran dan masing-masing akan memetik hasilnya (Jawa: becik ketitik ala ketara), atau (seperti pepatah- pantun) berakit-rakit kehulu berenang-renang

\footnotetext{
${ }^{4}$ http://konsepcinta-

sucimolidina.blogspot.co.id/2015/04/4-unsur-cintaoleh-erich-fromm.html
}

ketepian, setelah menderita, orang baru mengingat Tuhan ", dan sebagainya. Tema tradisional walaupun banyak variasinya, boleh dikatakan selalu ada kaitanya dengan masalah kebenaran dan kejahatan (Maredith \& Fizgerald, 1972;66).Tema non tradisional adalah tema yang menyangkut sesuatu yang tidak lazim/non tradisional. Karena sifatnya yang non tradisional, tema yang demikian mungkin tidak sesuai dengan harapan pembaca, juga bersifat melawan arus, mengejutkan, bahkan boleh jadi mengesalkan, mengecewakan, atau berbagai reaksi afektif yang lain.

$$
\text { Menurut Shipley dalam }
$$

Nurgiantoro (2000), terdapat lima tingkat tema, yatu tema tingkat fisik, tema tingkat organik, tema tingkat sosial, tema tingkat egoik, dan tema tingkat divine. Dalam tema tingkat fisik, tema karya sastra pada tingkat ini lebih banyak menyaran dan ditunjukkan oleh banyaknya aktivitas fisik daripada kejiwaannya. Ia lebih menekankan mobilitas fisik dari pada kejiwaannya.Tema tingkat organik, lebih banyak menyangkut dan mempersoalkan masalah seksualitas. Suatu aktivitas yang hanya dapat dilakukan oleh makhluk hidup. Tema tingkat ketiga adalah tema tingkat sosial, manusia sebagai makhluk sosial. Kehidupan bermasyarakat yang merupakan tempat aksi-interaksinya manusia dengan sesama dan lingkungan alam, mengandung banyak permasalahan, konflik, dan lain-lain yang menjadi objek pencarian tema. Tema tingkat keempat adalah tema tingkat egoik, manusia sebagai individu. Disamping sebagai makhluk sosial, manusia sekaligus juga sebagai makhluk individu yang senantiasa "menuntut" pengakuan atas hak individualitasnya. Sedangkan tema tingkat kelima disebut tema tingkat divine, manusia sebagai makhluk tingkat tinggi, yang belum tentu setiap manusia mengalami dan atau mencapainya. Masalah yang menonjol dalam tema tingkat ini adalah masalah hubungan 
manusia dengan sang pencipta, masalah religiositas, atau berbagai masalah yang bersifat filosofis lainnya seperti pandangan hidup, visi, dan keyakinan.

Di dalam novel Shiosai, tema cinta menjadi tema mayor karena beberapa hal. Pertama, cinta menjadi penggerak dan motivasi tokoh utama dalam menjalani kehidupannya di Utajima.Kedua, konflik yang dimunculkan dalam cerita berawal dari permasalahan cinta Shinji terhadap Hatsue. Ketiga, mendapatkan cinta Hatsue adalah tujuan yang ingin dicapai tokoh utama walaupun mendapat pertentangan yang keras dari keluarga Hatsue.

Selain alasan di atas, adanya hubungan yang kuat antara tema dengan unsur struktur lainnya membuktikan bahwa tema cinta menjadi tema mayor dalam novel Shiosai. Unsur struktrur tersebut yaitu tokoh dan penokohan, alur dan pengaluran, dan latar.

Dalam tokoh dan penokohan, Shinji digambarkan sebagai sosok protagonis yang mendapatkan empati dari pembaca karena sikapnya yang tabah dalam menghadapi ujian cinta dari ayahnya Hatsue. Berlawanan dengan Shinji, Mishima menggambarkan sosok antagonistik dalam diri Yasuo, anak orang kaya yang malas, yang menjadi rival Shinji dalam mendapatkan cinta Hatsue.

Dalam alur dan pengalurannya, cerita dalam novel ini digerakkan dengan alur progresif yang bergerak maju dari awal sampai akhir cerita. Pada tahap penyituasian, dipaparkan mengenai Shinji dan pertemuannya dengan Hatsue, seorang gadis yang memikat hatinya. Seiring dengan intensitas pertemuan kedua orang itu, benih-benih cinta mulai tumbuh subur dalam kedua orang itu, khususnya pada saat keduanya terpaksa berpelukan karena hebatnya badai yang melanda Utajima. Konflik kemudian dimunculkan dengan desas-desus yang beredar bahwa Shinji dan Hatsue telah melakukan perzinahan. Rumor tersebut mulai ditiupkan oleh Chiyoko yang merasa cemburu dengan kedekatan Shinji dengan Hatsue. Chiyoko menceritakan pertemuan Shinji dan Hatsue di saat badai kepada Yasuo dengan melebih-lebihkan ceritanya. Rumor itu pun cepat tersebar karena Yasuo merupakan ketua pemuda di Utajima sekaligus tunangan Hatsue.

Tahap konflik memuncak ditandai dengan sampainya rumor tersebut ke telinga Terukichi, yaitu ayah Hatsue yang kemudian melarang anaknya bertemu dengan Shinji. Rasa cinta yang membuncah dalam diri Shinji dan Hatsue membuat keduanya tetap berkomunikasi dengan sembunyi-sembunyi melalui Ryuji, teman Shinji. Ibu Shinji yang mengetahui cinta anaknya terhadap Hatsue berusaha untuk menemui ayahnya Hatsue dan meyakinkannya untuk mengawinkan Shinji dan Hatsue. Alih-alih bertemu, ayah Hatsue malah menolak untuk bertemu dengan ibunya Shinji sehingga menyebabkan ibu Shinji menjadi marah.

Suspense mulai mereda ketika Shinji dan Yasuo bekerja di kapal yang sama milik Terukichi. Bersamaan dengan itu, Chiyoko yang merasa berhutang budi kepada Shinji sekaligus merasa bersalah kepada Shinji mengungkapkan kepada ibunya bahwa dia tidak akan pulang ke Utajima apabila ibunya tidak membantu Shinji dan Hatsue untuk menikah.

Pada tahap akhir, ibunya Chiyoko dengan beberapa temannya mendaytangi Terukichi untuk mengatakan hal yang sesungguhnya tentang Shinji. Akan tetapi, di luar dugaan Terukichi mengatakan akan menikahkan Hatsue dengan Shinji. Pandangannya berubah terhadap Shinji ketika mengetahui kualitas kepribadian Shinji yang jauh di atas Yasuo. Ternyata Terukichi mempekerjakan Yasuo dan Shinji bersama-sama untuk mengetahui kualitas kepribadian mereka.

Dari tahapan pengaluran di atas dapat dikatakan bahwa tiap-tiap bagiannya berintikan seputar permasalahan cinta di antara Shinji dengan Hatsue. Cerita berakhir dengan happy ending dengan 
disetujuinya hubungan Shinji-Hatsue oleh Terukichi.

Latar sosial dalam novel ini adalah masyarakat nelayan di Utajima Jepang yang terdapat perbedaan status sosial yang cukup lebar antara yang kaya dan yang miskin. Akan tetapi, hal itu tidak menghalangi jalinan cinta antara Shinji dengan Hatsue yang berbeda status sosialnya. Shinji dari keluarga miskin, sedangkan Hatsue adalah putri dari Terukichi, seorang saudagar kaya pemilik kapal Utajima-maru. Sedangkan latar tempat utama adalah di Utajima, sebuah kampung nelayan di Jepang. Kaum lakilaki dewasa akan bekerja melaut berharihari untuk mendapatkan ikan demi memenuhi kebutuhan hidup keluarganya. Ujian cinta Hatsue dan Shinji di antaranya adalah ketika Hatsue dilarang ayahnya untuk bertemu dengan Shinji dan yang terberat adalah ketika mereka harus berpisah lama karena Shinji bekerja dikapal ayahnya. Dapat dikatakan latar tempat dan sosial dalam novel ini menguatkan dramatisasi hubungan cinta antara Shinji dan Hatsue.

Sedangkan berdasar dikotomi tradisional-nontradisional, maka tema novel Shiosai adalah tema yang tradisional karena menunjukkan anggapan umum masyarakat dimana kesabaran akan menuai hasilnya, dan cinta dan kebenaran akan meluluhkan hati seseorang. Kesabaran Shinji dalam menghadapi tantangan cinta dan penolakan Terukichi membuahkan hasil ketika akhirnya Terukichi memberi persetujuan untuk menikahkan Shinji dan Hatsue.

Berdasarkan tingkatannya, maka tema novel Shiosai adalah tema tingkat sosial karena novel Shiosai menceritakan kehidupan masyarakat nelayan di Utajima dengan berbagai konflik di dalamnya. Dalam hal ini adalah konflik dikarenakan cinta Shinji yang berasal dari keluarga miskin yang mencintai Hatsue yang merupakan anak Terukichi yang kaya.

\subsection{Bentuk-Bentuk Cinta dalam Novel Shiosai}

Berikut akan dijabarkan beberapa bentuk/jenis cinta dalam Novel Shiosai. Ada beberapa jenis cinta yang diungkap dalam novel ini yaitu cinta terhadap keluarga, cinta terhadap lawan jenis, dan cinta terhadap lingkungan. Penjabaran ini sekaligus sebagai bukti bahwa tema cinta merupakan tema mayor dalam cerita ini.

\section{Cinta Terhadap Keluarga}

Cinta terhadap keluarga terlihat ketika Shinji berkata dalam batinnya mengenai cita-citanya dan keinginannya mengobati ibunya seperti terlihat pada kutipan berikut.

「おれはいつか, 働らいて貯めた金で 機帆船買うて、弟と二人で、紀州の 木材や九州の石炭を輸送しようと思 っとるがな。そいでお母さんに楽を させてやり、年をとったらおれも島 にかえって、楽をするんや. . . (Mishima Yukio, 1954: Hal.56)

Ore wa itsuka, hataraite tameta kane de kihansen kaute, otōto to futari de, kishū no mokuzai ya Kyūshū no sekitan o yusō shiyou to omottoruga na. Soide okāsan ni raku o sa sete yari,-toshi o tottara ore mo shima ni kaette,-raku o suru n'ya...

"Pada suatu hari aku ingin membeli sebuah kapal pengangkut untuk pelayaran pantai dengan uang yang kuperoleh dan kutabung... dan menjadi pengusaha perkapalan dengan adikku, mengangkut batang-batang kayu dari Kishu dan batu sarang dari Kyushu... Lalu aku ingin kembali ke pulau dan mengobati ibuku.

Kutipan di atas menunjukkan cita-cita Shinji agar menjadi seorang yang sukses dan dari hasil keringatnya tersebut dia bertekad untuk meringankan beban ibunya dan berusaha mengobatinya dengan 
memberinya obat. Kutipan di atas menunjukkan pula terpenuhinya unsurunsur cinta menurut Fromm. Shinji menunjukkan rasa hormat (respect) terhadap ibunya, juga menunjukkan ada rasa tanggung jawab serta pengetahuan tentang kebutuhan ibunya.

2. Cinta Terhadap

Sahabat/Persahabatan

Selain cinta terhadap keluarga, terdapat pula bentuk cinta terhadap sahabat/persahabatan yang tercermin dalam kutipan berikut.

\section{毎朝水瓶の蓋にはさまれる手紙をと りにゆく役目は、家から港へ下りる 道筋が照吉こまの家の前をとおって いる龍二が、進んで買って出た。 \\ (Mishima Yukio, 1954: Hal.116)}

Maiasa mizugame no futa ni hasama reru tegami o tori ni yuku yakume wa,ka kara Minato e oriru michisuji ga Terukichi koma no ie no mae o tōtte iru Ryūji ga, susunde katte deta.

Ryuji yang melewati rumah Terukichi bila ia ke pantai dengan sukarela mengambil surat Hatsue dari bawah tutup tempayan air setiap pagi.

Kutipan di atas menunjukkan pada saat desas-desus tentang Shinji dan Hatsue semakin tersebar luas, dan pada akhirnya desas-desus itu sampai ke telinga Ayah Hatsue dan hal itu menyebabkan Hatsue tidak boleh lagi berhubungan atau bertemu dengan temannya itu, Ryuji dengan sukarela mengambil dan mengantarkan surat diantara mereka untuk menolong hubungan ataupun komunikasi Shinji dengan gadis itu tetap berjalan lancar. Tindakan Ryuji tersebut adalah hasil dari rasa empati dan hormat terhadap sahabatnya, serta adanya rasa tanggung jawab dengan mau menanggung kesusahan temannya untuk mengatasi problemnya.
3. Cinta Terhadap Tanah Air/Lingkungan

Rasa cinta terhadap Utajima ditunjukkan Shinji ketika dia berbicara dengan Hatsue mengenai cita-citanya yang ingin menjadi seorang yang sukses. Walaupun nantinya sukses, Shinji bertekad untuk kembali ke Utajima karena dia mencintai tanah kelahirannya tersebut.

じこを航海していても、島のことを
忘れず、島の景色が日本で一番美え
ように。。。(Mishima Yukio, 1954:
Hal.56)

Berlayar kemanapun, aku tak akan melupakan segala hal tentang pulau ini, pulau ini adalah yang terindah di Jepang

\section{Cinta Terhadap Lawan Jenis}

Bentuk cinta yang terakhir adalah cinta terhadap lawan jenis yang merupakan bentuk cinta yang paling banyak diungkap dalam novel Shiosai. Yang utama dan paling banyak adalah rasa suka dan cinta Shinji terhadap Hatsue seperti yang terlihat pada dua kutipan berikut.

\section{こうしてじっと坐っているだけなの に、はげしい労働の際にしか見られ ない変化が起ってくるのは、気味が わるい。彼は自分の煩に掌をあてて みた。その熱い煩は他人の㚘頁のよう な気がした。自分にわからないもの の存在は彼の㐨りを傷つけ、怒りは 彼の煩を尚のこと真赤にした。 (Mishima Yukio, 1954: Hal.23-24)}

Kōshite jitto suwatte iru dakenanoni, hageshī rōdō no sai ni shika mi rarenai henka ga okotte kuru no wa, kimi ga warui. Kare wa jibun no hoho ni tenohira o atete mita. Sono atsui hō wa tanin no hoho no yōna ki ga shita. Jibun ni wakaranai mono no sonzai wa kare no awari o kizutsuke, ikari wa kare no hoho o nao no koto makka ni shita. 
Timbul perasaan asing untuk duduk di sana tanpa bergerak dan merasakan dalam dirinya perubahan-perubahan fisik yang hingga saat ini Cuma dialami bila bekerja berat. Ia meletakkan telapak tangan di pipinya untuk merasakannya. Perasaan hangat yang dirasakan itu betul-betul asing baginya bila menyadari adanya sesuatu di dalam dirinya yang selama ini tidak begitu diharapkan dan kegusarannya yang meluap membuat kedua pipinya bertambah panas.

新治はすこしも物を考えない少年だ ったが、この一つの名前は非常な難 問のようにわずら彼の心を患わせて やまなかった、名前をきくだけで㚘 がほてり胸が弾んだ。こうしてじっ と坐っているだけなのに、はげしい 労働の際にしか見られない変化が起 ってくるのは、気味がわるい。彼は 自分の煩に掌をあててみた。その熱 い㥧は他人の煩のような気がした。 (Mishima Yukio, 1954: Hal.23)

Shinjiwa sukoshimo mono o kangaenai shōnendattaga, kono hitotsu no namae wa hijōna nanmon no yō ni wa zura kare no kokoro o wazurawa sete yamanakatta, namae o kiku dake de hoho ga hoteri mune ga hazunda. Kōshite jitto suwatte iru dakenanoni, hageshī rōdō no sai ni shika mi rarenai henka ga okotte kuru no wa,-gimi ga warui. Kare wa jibun no hoho ni tenohira o atete mita. Sono atsui houwa tanin no hou no yōna ki ga shita.

Shinji tidaklah selamanya memikirkan tentang sesuatu tapi untuk nama yang satu ini, seperti sebuah tekateki yang menggoda, tetap mengganggu pikirannya. Bila nama itu makin nyaring terucapkan, pipinya makin merah dan detak jantungnya tambah keras. Timbul perasaan asing untuk duduk di sana tanpa bergerak dan merasakan dalam dirinya perubahan-perubahan fisik yang hingga saat itu Cuma dialami bila bekerja berat. Ia meletakkan telapak tangan di pipinya untuk merasakannya. Perasaan hangat yang dirasakan itu betul-betul asing baginya.

Dua kutipan di atas menunjukkan perasaan Shinji yang mulai merasakan getaran yang tidak biasa setelah pertemuannya dengan Hatsue.Selain cinta Shinji terhadap Hatsue atau sebaliknya, di dalam novel juga terdapat kutipan-kutipan lainnya yang menunjukkan rasa cinta atau suka terhadap lawan jenis, misalnya perasaan suka Chiyoko terhadap Shinji.

Walaupun menyukai Hatsue, tetapi Shinji tidak bertindak di luar batas dengan mengajak Hatsue kawin lari ketika ayah Hatsue melarang anaknya untuk bertemu dengannya. Rasa hormat dan tanggung jawabnya terhadap kepercayaan Hatsue bahwa cinta mereka akan menang adalah bukti adanya cinta yang murni pada diri Shinji dan Hatsue.

\section{SIMPULAN}

Dalam sebuah bangunan karya sastra, setiap struktur di dalamnya mempunyai pertalian dan hubungan antara satu struktur dengan yang lainnya. Dalam novel Shiosai, tema cinta menjadi tema mayor dan menjadi landas tumpu bagi struktur lainnya. Sebaliknya tema tersimpulkan dengan adanya kaitan antara struktur lainnya seperti tokoh dan 
Izumi, Volume 6, No 1, 2017

e-ISSN: 2502-3535, p-ISSN: 2338-249X

Tersedia online di http://ejournal.undip.ac.id/index.php/izumi

penokohan, alur dan pengaluran, latar dan yang lainnya.

Novel Shiosai memiliki ciri khas tersendiri dibandingkan dengan karya sastra karangan Mishima Yukio lainnya seperti Kinkakuji dan Yuukoku. Kesan cerah akan dirasakan setelah membaca
Shiosai dibandingan ketika membaca Kinkakuji dan Yuukoku yang bernuansa kurai(gelap). Akhir cerita yang jelas dan happy-ending menambah kesan ringan cerita ini.

\section{DAFTAR PUSTAKA}

Mishima, Yukio. 1954. Shiosai. Tokyo: Shinchosha.

Nurgiyantoro, Burhan. 2000. Teori Pengkajian Fiksi. Yogyakarta: Gajah Mada University Press.
Pradopo, Rachmat Djoko. 2012. Beberapa Teori Sastra, Metode Kritik, dan Penerapannya. Pustaka Pelajar. Yogyakarta:

\section{DAFTAR LAMAN}

http://digilib.uinsby.ac.id/10874/5/bab\%202.pdf

http://www.bukukerja.com/2014/01/hakikat-novel-sebagai-karya-sastra.html

http://www.mishimayukio.jp/history.html

http://konsepcinta-sucimolidina.blogspot.co.id/2015/04/4-unsur-cinta-oleh-erich-fromm.html 